\title{
Re-writing the Colonial Story in Mircea Eliade's Maitreyi and Maitreyi Devi's Na Hanyate
}

\section{Arina Cirstea ${ }^{*}$}

This article discusses the relationship between reading and cultural stereotyping in two fictional writings that engage with the same biographical material. In 1933, Romanian writer Mircea Eliade published a semi-autobiographical novel, Maitreyi (Bengal Nights), inspired by his recent experience as a student in an Indian university. Nearly forty years later, the echoes of this story reached Calcutta, prompting the response of the novel's protagonist, poet and human rights militant Maitreyi Devi, which appeared in 1971 as Na Hanyate (It Does Not Die). These conflicting stories, beyond their individual significance, reflect problems of cultural representation - moving among a variety of different discourses, from Enlightenment rationalism and modernism to nationalism and feminism. The aim of my analysis is to highlight the different cultural discourses that are responsible for various shifts in the composition and interpretation of these texts, and implicitly contribute to their more adequate positioning within the context of world literature. [Article copies available for a fee from The Transformative Studies Institute. E-mail address:_ journal@transformativestudies.org Website: http://www.transformativestudies.org (C2013 by The Transformative Studies Institute. All rights reserved.]

KEYWORDS: Mircea Eliade, Maitreyi Devi, Subaltern Cultures, World Literature, India, Romania.

\section{PRELIMINARIES}

$20^{\text {th }}$ century researchers from various humanistic fields agree that, in the modern world, the encounter between two cultures can no longer take

\footnotetext{
* Arina Cirstea, Ph.D., is Associate Fellow, Department of English and Comparative Literary Studies, University of Warwick, UK. Address correspondence to: Arina Cirstea, Department of English and Contemporary Studies, University of Warwick, Gibbet Hill Rd, Coventry, CV4 6AL, UK; e-mail: a.cirstea@warwick.ac.uk.

Acknowledgements: I would like to thank dr Rashmi Varma (University of Warwick) for her helpful comments on this article.
} 